\title{
DO DUALISMO AO ORNITORRINCO: entrevista com Francisco de Oliveira ${ }^{1}$
}

\author{
Marcelo Siqueira Ridenti \\ Flávio da Silva Mendes*
}

\begin{abstract}
Em 2012, o ensaio "Crítica à razão dualista", de Francisco de Oliveira, completou 40 anos. Nesta entrevista, o sociólogo pernambucano radicado em São Paulo expõe algumas das referências teóricas e políticas que o levaram à elaboração daquele texto clássico. Discute, também, outros trabalhos importantes ao longo de sua trajetória intelectual, desde os artigos ainda inspirados pelo dualismo de Celso Furtado, nos anos 1960, até a criativa metáfora do ornitorrinco, à qual recorre para compreender o Brasil atual. Nesse percurso, revisita trabalhos dedicados à região nordeste, aos desafios da redemocratização da sociedade brasileira, à trajetória dos intelectuais do país, ao Partido dos Trabalhadores e ao avanço do neoliberalismo, já nos anos 1990. No final, não se esquiva de realizar comentários sobre a atual conjuntura nacional. Esperamos que este material contribua para o debate sobre sua obra e inspire, mais uma vez,
\end{abstract} reflexões sobre a realidade brasileira.

Marcelo Ridenti: Nesta entrevista, nós estamos interessados em discutir sua obra.

Chico de Oliveira: Que obra? Marx um dia perguntou: “que obra?” (risos).

Flávio Mendes: Na outra entrevista à Margem Esquerda, você falou a mesma coisa. Se não for a obra, pelo menos a trajetória.

Chico: Trajetória é melhor, eu me reconcilio melhor com essa ideia do que com a de obra. Eu tenho um texto importante, dos anos 1970, que é Crítica à razão dualista. Os outros não tiveram tanta importância.

Flávio: Você tem dois artigos anteriores que foram publicados na Revista Civilização Brasileira. Um de 1965, que é uma crítica ao programa econômico do Castello Branco, e um de 1966, sobre planejamento. Minhas perguntas são sobre esses dois textos, duas perguntas na verdade: Eu queria que você

* Doutor em Sociologia. Professor Titular de Sociologia na Universidade Estadual de Campinas - UNICAMP. Departamento de Sociologia - IFCH. Cidade Universitária. Cep: 13081-970 - Campinas - São Paulo - Brasil. mridenti@unicamp.br

** Doutorando em Sociologia. flavio85@gmail.com

${ }^{1}$ Entrevista realizada na residência de Chico de Oliveira em São Paulo, em 13 de abril de 2012. falasse sobre os temas deles. Quais eram as propostas desses dois artigos? E, também, como você chegou à Civilização Brasileira?

Chico: Nessa época, eu fiquei muito no Rio de Janeiro. Eu estava, na sequência do golpe, saindo de Recife e fiquei no Rio de uma forma bastante provisória, sem emprego, fazendo bicos, e me aproximei do grupo que o Ênio Silveira reunia. Era um grupo de esquerda, majoritariamente do Partidão [Partido Comunista Brasileiro], porque ele próprio era militante do Partidão. E eu me aproximei daquele grupo. Foi quando ele estava lançando a Revista Civilização Brasileira, e eu fiz o primeiro artigo, que foi sobre o Castello Branco. Foi escrito como uma peça de oposição à ditadura. Ele tem um título farsesco, porque diz que não vai dar certo e deu (risos). Fazia parte de uma frente de oposição, que era muito louvável, contra o Roberto Campos, era o mentor, o Bulhões... A gente queria cutucar o cão com vara curta. Esse é o contexto em que foi produzido. Não tem grande coisa.

Marcelo: Esse pessoal da revista se reunia com frequência?

Chico: Não se reunia com frequência, não era uma 
coisa organizada. Mesmo porque o Ênio tinha muito medo de ser organizado porque ele era do Partidão e ele sabia os riscos. O Partidão tirava castanha do fogo com mão de gato. Quer dizer, como ele era rico, o Partidão queria meter a mão. Ele dizia: 'Olha, eu sou comunista, mas essa livraria aqui é minha tá, não é do partido'. Era mais ou menos espontâneo.

Marcelo: Quem participava? Ferreira Goulart, Dias Gomes, Paulo Francis?

Chico: Não. Era Moacyr Félix, talvez Paulo Francis tenha ido uma vez.

Marcelo: O Octavio Ianni chegou a participar de algumas coisas?

Chico: Não. O Ianni morava em São Paulo. Ele publicava às vezes e era muito prestigiado pela editora. Acho que, naquela fase, todos os livros dele saíram pela Civilização Brasileira, mas ele não ia.

Marcelo: Na Crítica à razão dualista, há um tom autocrítico em relação a esses artigos, porque você estava ainda muito próximo das ideias do Celso Furtado naquele momento, não é?

Chico: Muito. Ali eu começava a me dar conta, de forma consciente, e a tentar fazer a crítica à CEPAL. O outro artigo é mais fraco. Eu tentava pensar exatamente como o título diz. Porque o planejamento estava muito associado à experiência socialista. Eu tentava pensar de outra forma, porque o planejamento entrava na agenda de sociedades desenvolvidas.

Flávio: Uma antecipação de um tema que você retomou em Elegia para uma re(li)gião, dez anos depois?

Chico: Mas não com aquele enfoque. Já era um pé atrás com o furtadismo, que fazia do planejamento uma espécie de panaceia. Até porque fazia muito parte da conjuntura. O [Roberto] Campos insistia muito no planejamento, como se a ditadura estivesse fazendo planejamento. Eu escrevia nessa frente de oposição. A ideia era muito associada ao socialismo e a dar um anteparo a essa visão. Mas não é um artigo que seja referência para nada.

Flávio: Ainda sobre ele, o Marcelo citou que ainda existia ali uma relação forte com o Celso Furtado, mas começava a aparecer certo distanciamento. Eu queria saber o que inspirava, naquela época, esse distanciamento. Na entrevista à Margem Esquer$d a$, você disse que tinha um projeto de fazer uma pesquisa com o Florestan Fernandes e que o projeto se perdeu. Foi nessa época pós-golpe também? Você tinha um pouco de contato com o pessoal que depois seria do CEBRAP [Centro Brasileiro de Análise e Planejamento]?

Chico: Não tinha. Seria muito nobre dizer que sim. A história do Florestan foi acidental. Eu entreguei o meu projeto de mestrado ao Gabriel Bolaffi, um grande amigo que eu tinha em São Paulo, e ele perdeu (risos).

Marcelo: Isso era 1965?

Chico: Eu já estava em São Paulo.

Flávio: Então deve ser 1968 ou 1969, um pouco antes do Florestan ser aposentado. E você lembra o tema do projeto?

Chico: Eu lembro que tive uma conversa muito breve com Florestan e foi a partir dela que o projeto surgiu. Na verdade, eu queria pensar e experiência da SUDENE [Superintendência do Desenvolvimento do Nordeste]. Eu só fui fazer isso muito tempo depois. Mas foi melhor, vendo em retrospectiva. Eu ia fazer uma coisa muito furtadiana. Eu não tinha ainda o afastamento suficiente. Era uma tentativa. Eu não tinha muito contato com o Florestan.

Flávio: Você o conhecia como, através do Octavio Ianni?

Chico: Era mais pelo Octavio. Eu era muito amigo do Octavio. Nós o levamos várias vezes para cursos na SUDENE. E ele foi uma das pessoas que me acolheram. Nós nos tornamos muito amigos. Eu não tinha nada a ver com as intrigas de São Paulo, eu não sou daqui, portanto não sabia. Eu sabia que o Fernando Henrique, que fazia par com ele, tinha uma diferença. Para fazer uma história das ideias que tenha que ver com conjuntura histórica, de fato, Octavio era mais superficial do que o Fernando Henrique. Ele era mais engajado, mas, de fato, a produção dele era um pouco mais superficial do que a de Fernando Henrique.

Flávio: Aí, em seguida, o Ianni te convidou para o CEBRAP? 
Chico: O Octavio estava fazendo um projeto que ia ser patrocinado pela Academia Brasileira de Ciências. Ela dava o dinheiro e repassava esse dinheiro para o CEBRAP. O projeto era sobre planejamento. Ele cuidava da parte de planejamento no Brasil e me convidou para fazer a parte de planejamento regional. Esse projeto fracassou, também, porque o governo puxou o tapete. Mas eu já estava lá, o Octavio já tinha começado a trabalhar, e, a partir dali, eu comecei a pensar mais sobre o planejamento regional, mas não escrevi nada que prestasse. Só depois.

Marcelo: Você disse que, felizmente, não fez naquele momento um texto avaliando a experiência da SUDENE, porque você ainda estaria muito próximo das ideias do Furtado. Essa sua entrada no CEBRAP teve um sentido de mudança, um momento decisivo no seu pensamento? $\mathrm{O}$ contato com esse pessoal, o José Arthur Giannotti, o Fernando Henrique, o José Serra?

Chico: Não, o Serra nunca foi do CEBRAP. A vida toda ele nunca foi, de fato. O Fernando Henrique tratava de puxá-lo. Ele estava no Chile, depois conseguiu regressar. Mas ele nunca foi, de fato. A entrada no CEBRAP foi decisiva. Eu acho que foi a grande aquisição que tive nos anos 1970. Porque aí eu me enderecei decisivamente para pensar a sociedade através do marxismo. Havia um ambiente muito estimulante. O Giannotti era a figura principal do ponto de vista teórico. O Fernando Henrique era uma pessoa muito estimulante na época do CEBRAP, ao contrário do que ele depois veio a ser. Ele era uma pessoa muito estimulante. Havia um conjunto de pessoas. O Juarez Brandão Lopes, embora não fosse marxista, era uma pessoa muito aberta. Era um grupo muito interessante. Vinha gente de fora várias vezes - Pedro Malan, Maria da Conceição Tavares -, para o famoso “mesão", que era uma reunião, uma discussão que havia periodicamente. Pegava-se um texto importante, fazia-se a discussão. E estávamos ainda numa época em que não se faziam reverências. Então, o pau cantava de forma realmente bastante livre. Depois, não. Depois já vieram as reverências. Fernando Henrique não era nada naqueles anos, não era nem conhecido no Brasil. A gente teve a fase meio missionária: a gente saía pelo Brasil fazendo conferências e eu testei isso várias vezes. $\mathrm{O}$ CEBRAP ninguém sabia o que era. Todo mundo pensava que era um armazém de secos e molhados... Marcelo: O Fernando Henrique tinha feito o livro com o Enzo Faletto, que teve certa visibilidade na América Latina. [(Cardoso; Faletto, 1975)]

Chico: Mais na América Latina do que no Brasil. Mas, de qualquer forma, ele era um sujeito muito estimulante.

Marcelo: E era o articulador político?

Chico: Era o articulador político. O CEBRAP foi, em grande medida, obra dele. Porque ninguém ia fazer um instituto daquele, em plena ditadura, se não tivesse cobertura. Não sei muito bem da história, porque eles tinham segredos de estado que não revelavam. Muito da cobertura veio de Paulo Egídio Martins, que era governador de São Paulo. Velho udenista, ele garantiu, segundo contam, que o instituto não ia tentar fazer oposição, não era para isso. Calhou que, naqueles anos, havia uma liderança progressista na Fundação Ford. O sujeito que dirigia intelectualmente o auxílio da Fundação Ford a várias instituições de pesquisa era um porto-riquenho de esquerda, que estava nos Estados Unidos e que ajudou muitas instituições. $\mathrm{O}$ Torcuato Di Tella era praticamente sustentado pela Ford. Essas coisas se encaixaram, e a Fundação Ford dava o dinheiro. Mas, de fato, nunca interferiu na temática, até onde eu posso ter percebido. Havia coisas por baixo do pano.

Marcelo: Vocês tinham um salário para fazer parte das pesquisas?

Chico: Não, a gente tinha uma bolsa da Ford. E o dinheiro era complicadíssimo. O dinheiro vinha via Cândido Mendes, do Rio de Janeiro. Cândido Mendes transferia para o CEBRAP. Era uma operação arriscada. A ditadura sabia.

Marcelo: A Crítica à razão dualista já resulta desse convívio?

Flávio: Você falou, em alguns debates, que ela foi uma resposta ao Fernando Henrique. O Paul Singer também escreveu um livro em resposta. Qual era esse debate? 
Chico: Esse debate é o que está no livro do Fernando [Henrique Cardoso (1975)] Autoritarismo e democracia. A tese do Fernando é que a ditadura era a revolução burguesa no Brasil. Tinha certa razão, do ponto de vista que de que ela quebrou certas resistências oligárquicas para limpar o terreno. Mas foi em reação a essa tese que eu elaborei a Crítica à razão dualista, e o Paul fez uma crítica econômica ao Fernando. São as duas peças com as quais nós enfrentamos a posição do Fernando Henrique.

Marcelo: Florestan Fernandes [(2006)], em A revolução burguesa no Brasil, coloca a revolução burguesa como um processo, e a ditadura militar como coroando esse processo por uma via autoritária. É um pouco diferente do encaminhamento do Fernando Henrique, mas, de alguma maneira, chegando a um resultado parecido.

Chico: Chegam próximo, mas o Fernando Henrique escreve antes. Enfim, essas ideias estavam mais ou menos no ar naquele grupo que o Florestan, de alguma maneira, criou. Fernando Henrique antecipou, mas nunca deu o acabamento teórico completo. Quem vai dar é Florestan, em A revolução burguesa no Brasil.

Flávio: Florestan escreveu uma parte logo depois do golpe de 1964, em 1966, e só foi terminar o texto em 1974. Então, o livro do Fernando Henrique deve trazer algumas ideias do debate com o Florestan

Chico: Deve trazer, porque eles eram muito próximos. OFernando Henrique fazia parte daquele grupo que o Florestan criou. Ele foi seu pupilo predileto. Era um grupo: ele, o Octavio, Maria Sylvia [Carvalho Franco]. Devia ter algumas ideias que circulavam entre eles, e o Fernando se antecipou naqueles tempos do CEBRAP, mas ele nunca elaborou de uma forma mais acabada. Isso aí quem vai fazer é o Florestan.

Flávio: E como Crítica à razão dualista foi recebido? Ele foi publicado pela primeira vez pelo CEBRAP. Foi discutido lá dentro, teve muitas críticas?

Chico: Foi, foi muito discutido. Eu me assustei, achei que o texto era banal. Foi muito discutido, várias sessões. Florestan veio para discutir, Caio
Prado veio discutir. Foi muito interessante. Houve uma recepção muito forte, e eu me surpreendi, estava dizendo coisas mais ou menos sabidas. Depois foi que eu percebi, vendo em retrospecto, que havia uma distinção forte entre os cariocas e os paulistas do ponto de vista intelectual. A velha divisão entre cariocas e paulistas também existe nesse terreno. Quer dizer: os cariocas conheciam o Brasil, mas a teoria era fraca. Os paulistas não conheciam o Brasil, e a teoria era forte. Quando eles se encaminharam para o mítico seminário do Capital, do qual eu não participei, evidentemente, porque não morava aqui, eles entendiam muito pouco do Brasil. Enquanto que o Rio, pelo fato de ter sido capital, tem uma produção que é muito mais entranhada com a realidade brasileira do que São Paulo. Depois isso muda, e o eixo passa a ser São Paulo.

Flávio: Você falou que essa produção, principalmente do CEBRAP, era rica teoricamente, mas ainda conhecia pouco o Brasil. Você acha que sua experiência na SUDENE, o fato de trazer a questão do Nordeste, foi uma novidade ali naquele ambiente que talvez tenha despertado essa atenção grande da Escola Paulista?

Chico: Talvez sim. O fato era que eles conheciam muito pouco. O marxismo deles era muito acadêmico. Era de bom nível, mas era muito acadêmico. E conheciam muito pouco o Brasil. Então, o que eu trouxe foi experiência de vida. Teoricamente, eu era fraco. Tanto que, se você vai ver, as minhas referências bibliográficas são quase nulas. Eu tirei a viola do saco não sei como. Era muito da experiência que a SUDENE me deu, porque a SUDENE, no fim das contas, era um órgão governamental, então você conhecia por dentro como funcionava o Estado brasileiro, pelo menos naquela parte referente à questão regional. Eu fui militante socialista no Recife. Recife era uma cidade operária. Para alguém de esquerda, era difícil ser indiferente àquela experiência operária. O Partido Comunista era muito forte no Recife. Eu não fui do partidão, mas meus colegas de geração quase todos foram. Eu trazia uma experiência muito vivida. Era teoricamente frágil, mas muito mergulhada. Não era uma 
experiência de participação política mais séria. E eu observava muito. Se você tiver olhos para ver, você aprende muito.

Marcelo: No meu tempo de estudante, no fim dos anos 1970, li a Crítica à razão dualista e A revolução burguesa. Minha tendência, na época, era ver os textos quase como complementares, não como teses diferentes. Em que você discordava do Florestan e do Fernando Henrique?

Chico: O centro é o dualismo.

Marcelo: Você acha que eles ainda estavam presos ao dualismo?

Chico: Eles ainda estavam presos a categorias dualistas. Muito matizadas, evidentemente. Florestan tinha uma cultura marxista muito ampla, que só se revela depois, quando ele se radicaliza. Mas Florestan, nos anos 1940, traduzia Marx. O dualismo está muito matizado naquele texto em que, segundo todas as vozes, ele era funcionalista. O centro da divergência era o dualismo, e nisso a minha experiência de vida me ajudou muito, trouxe essa contribuição. Porque eu via as coisas de forma muito engrenada. Não aquela repartição esquemática entre atraso e progresso. Era, ao mesmo tempo, a força-impulso e o freio. Eu acho que o centro da divergência era a tese dualista.

Flávio: Seu texto também é bastante crítico à produção de Celso Furtado e da CEPAL em geral. Mas depois, mais tarde, você disse que aquela crítica foi muito pesada. O que fez com que fosse uma crítica tão pesada? Foi a influência do pessoal do CEBRAP?

Chico: Foi. Não que eles estivessem se dirigindo contra Furtado, foi uma interpretação minha. Mas era muito pesada e muito injusta. Há certas passagens da vida em que você vê inimigos por todo lado (risos). Eu achava que o Furtado era o inimigo, mas ele não era. Então, eu me redimo de uma crítica ideológica que foi muito injusta.

Marcelo: Na opinião desse pessoal da USP, o Furtado, sim, é que seria dualista. Eles nunca vestiram a carapuça.

Chico: Eles nunca vestiram, mas eles eram. Eles eram de uma forma mais matizada. O Furtado nun- ca se meteu a marxista. Isso deve ser dito em honra da integridade intelectual dele. Ele leu Marx, mas ele claramente tentava uma alternativa. O pessoal da USP não se achava dualista. Existia, dentro do pensamento deles, a divisão entre atraso e progresso, de forma mais matizada, de forma mais elaborada, mas existia. Você encontra isso em Florestan, encontra isso de maneira muito forte em Fernando Henrique. Mesmo em Octavio há essa distinção dual.

Marcelo: E você está ali mostrando como o supostamente moderno se alimenta e é indissociável do atraso.

Chico: É indissociável do atraso. Nas condições periféricas, você é quase obrigado a fazer "progresso", entre aspas, pela via atrasada. Eu via isso na zona da cana de Pernambuco. Era visível. Ali tinha um amálgama que a esquematização não resolvia.

Flávio: E nesses debates que se seguiram à publicação do texto, com Florestan, Caio Prado, o Fernando Henrique deve ter participado também, essa questão do dualismo aparecia? Foi debatida? Qual era o teor desse debate? Era mais aceitação ao texto ou crítica?

Chico: Foi muita aceitação, eu não esperava. Havia um intercâmbio muito forte com o Rio. O Antônio Barros de Castro veio num desses seminários e chamou o texto de funcionalista. A resposta não veio de mim, veio do Giannotti. O Giannotti deulhe uma lição de funcionalismo. E ainda disse, de forma como lhe é comum: se você quiser, eu te dou uma bibliografia (risos). Era um debate muito interessante e muito vivo. Havia pouca reverência. Marcelo: O Roberto Schwarz fazia parte também nessa época? Já estava no Brasil?

Chico: Não estava. Roberto, depois que voltou, passou a ser uma presença assídua. Mas nessa época quente ele não estava.

Marcelo: Isso foi 1972, 1971?

Chico: Era. O Roberto não estava. Ele não tinha voltado ainda. O problema deles com o Crítica à razão dualista, em geral, era São Paulo: qual era o lugar de São Paulo, naquela estrutura teórica, em primeiro lugar, e no desenvolvimento dialético dessa troca entre atrasado e moderno. Havia uma 
dificuldade que eles atribuíam a mim, de não entender o lugar de São Paulo nesse capitalismo. Não havia discordância de fundo, digamos assim. Foi muita gente de fora discutir. Bresser Pereira era muito presente lá, Eduardo Suplicy. Do Rio vinham com frequência o Pedro Malan, a Maria da Conceição Tavares, Antônio Barros de Castro.

Flávio: O Paul Singer [(2006)] falou num texto que você era considerado o economista do CEBRAP naquela época. O pessoal ali tinha uma formação mais na área de sociologia, ligada ao Florestan, e você era visto como um economista que trazia mais temas econômicos para dentro do CEBRAP. Para eles, era uma coisa nova em relação à produção que eles faziam?

Chico: Sim, isso era um problema, de fato. Espantou-me muito quando eu comecei a me interar da formação que eles fossem tão toscos em economia política. O que era uma contradição. Eles estavam treinados em Marx. Isso me espantou muito. Então, eu era considerado economista (risos).

Marcelo: E você não mencionou, mas o Paul Singer também fazia parte desses debates desde o início. Era o outro economista?

Chico: Fazia, era o outro economista.

Flávio: Vocês eram os mais próximos? Você, o Paul Singer e o Octavio Ianni?

Chico: Não, minha proximidade maior era com o Fernando Henrique. Do ponto de vista da elaboração. Não era com o Paul. O Paul é muito didático, muito certinho. Ele pesquisa, de fato. Tanto que, para contestar o Fernando Henrique, ele reconstituiu, como podia, as teses de renda, de salário, na economia brasileira, para tentar mostrar que o milagre se devia ao arrocho salarial, o que parecia uma doidice completa. Porque a sensação que se tinha era de que havia avanço do salário real. Ele foi aos dados e mostrou que o que havia era um tremendo arrocho. Mas o meu diálogo maior era com o Fernando Henrique, que, naqueles anos, era muito mais sofisticado do que veio a ser depois. Com o Octavio eu tinha uma relação muito afetiva.

Marcelo: E o Octavio participava de todas as reuniões também?
Chico: Todas. O Octavio tinha uma presença muito forte. Ele era do quadro do CEBRAP, então ele estava em todos os debates, todas as intervenções. Ele sofria uma discriminação do Fernando Henrique, segundo diziam. Mesmo eu, que era recém-chegado, que não conhecia essa transa mítica, percebia no ar que ali havia um problema. O Octavio estava sempre perto, estava em todos. Francisco Weffort também, que montou um grupo de estudos sobre o movimento operário muito original. Fez um estudo que era o melhor na época sobre as greves de Osasco. Era um ambiente muito estimulante. De fato, ali eu dei a virada e me afastei da CEPAL.

Flávio: Depois vem o texto de 1977, Elegia para uma re(li)gião. Nele, você realizou seu projeto de análise da experiência da SUDENE já com o instrumental do CEBRAP?

Chico: Sim, ali é um ajuste de contas com o meu passado cepalino.

Marcelo: Na entrevista que você deu à Margem Esquerda, você desdenhou, de certa maneira, desse livro, dizendo que é um livro que já está ultrapassado. Você disse isso naquele dia e não foi aprofundado: "esse é um livro sobre o passado, não tem mais nada a ver". Pode falar um pouco mais?

Flávio: Quando escreveu A noiva da revolução, você disse que a ideia de região que está contida em Elegia para uma re(li)gião não teria mais serventia. Porque o nordeste pensado como uma região diferenciada dentro da nação já teria acabado. Eu queria que você falasse um pouco sobre essa visão.

Chico: Eu acho que aquela discussão sobre região já não faz sentido. Até o título foi escolhido de propósito. Elegia é uma espécie de nostalgia. Primeiro porque a economia do nordeste era muito autárquica. Fora a relação do açúcar com mercados externos, a economia do nordeste, em geral, era muito autárquica. Virava sobre ela mesma. Isso se refletia em todos os setores da vida. Você encontrará o melhor português falado no Maranhão. O melhor português falado no Brasil é do Maranhão. Devido a quê? Ao isolamento. Não é qualidade 
linguística. Isso também a história faz. E assim era em todos os setores, da economia, sobretudo. Fora a relação com o mercado externo de açúcar, a economia era muito autárquica. Isso mudou. A SUDENE começa a ser um agente dessa mudança. Não é ela que completa, mas ela dá início. Embora todos os nordestinos fossem autonomistas, o Celso Furtado não era. Todos nós pensávamos que, se o nordeste fosse uma nação separada, seria melhor, menos o Celso (risos). Ele nunca alimentou essa ilusão. Eu tinha um amigo que já morreu, ele dizia: "Nós temos petróleo, nós temos álcool". E ele não era nada tosco, era um engenheiro químico da maior qualidade. Havia uma ideia de autonomia pela qual, felizmente, a SUDENE não enviesou. E houve uma progressiva integração do nordeste ao circuito da economia brasileira, à forma de reprodução da economia brasileira. De modo que as diferenças existem do ponto de vista do nível de riqueza ou de pobreza, mas não do movimento dinâmico da economia. Isso não existe mais. Flávio: No livro, você apresentou esse processo como uma tragédia: a integração nacional como uma tragédia. Não só para as classes dominadas, mas também para as classes dominantes, porque você fala que elas não enxergavam que aquele projeto de integração nacional as destruía também.

Chico: O regionalismo sempre foi uma arma de extorquir recursos do governo federal e de arrochar internamente. E elas, as classes dominantes nordestinas, não perceberam que, com a integração, estavam condenadas a desaparecer como classes dominantes. Você não encontra mais hoje, em nenhuma parte do nordeste, a presença ostensiva de grupos das classes dominantes no comando do Estado.

Marcelo: Tasso Jereissati não seria uma exceção?

Chico: Não, não é não. Tasso é aqui do Shopping Center Iguatemi. Não tem nada a ver com o Ceará. Tasso Jereissati é uma invenção do grupo Iguatemi. O interesse dele está muito mais aqui do que lá, embora ele mande muito lá. Da onde vem a fortuna de Jereissati?

Marcelo: Mas deve ter mais coisas também, não? Chico: O Iguatemi já é consequência. A fortuna do
Jereissati vem de Vargas. Na verdade, era o Estado brasileiro que distribuía as cotas de moagem de trigo pelas várias regiões. E o Carlos Jereissati, que foi avô ou bisavô do Tasso, recebeu uma cota no Ceará. Você imagina isso no Ceará. Lá não tinha porto que prestasse, então ele estava isolado. Você ter o monopólio do trigo no Ceará era doce de coco. É daí que vem. Depois, o Banco do Nordeste criou toda uma burguesia cearense metendo dinheiro neles. Porque o banco não tinha onde aplicar recursos. Ele recebia $2 \%$ da receita orçamentária da União, coisa assim, e isso era para o Nordeste. E a maior parte ia para o Banco do Nordeste. Ele não tinha o que fazer. Então ele criou, na verdade, uma nova burguesia, sobretudo no Ceará, e Tasso Jereissati é produto disso, com a herança do cartório do trigo, que é um verdadeiro cartório.

Marcelo: Isso não se coloca localmente, esse é o seu ponto? Não tem mais uma burguesia local, como você colocou no seu texto sobre a Bahia, $O$ elo perdido?[(1987)]

Flávio: A reprodução o capital se dá fora do nordeste?

Chico: Se dá fora, não tem mais uma coisa ostensiva. Quem mandava no Ceará antes da geração Jereissati? Padre Cícero! Por incrível que pareça. No Maranhão, era Vitorino Freire, um político pernambucano que se deslocou para lá. Agora, a gente pensa que é Sarney. Antes dele, foi Vitorino Freire. Sarney deslocou Vitorino Freire. No Rio Grande do Norte, os Alves não são propriamente uma burguesia. Eles entraram pela política e, evidentemente, meteram-se em negócios. Na Paraíba, qualquer que você apanhasse, vinha o sobrenome Ribeiro Coutinho: usineiros. Em Pernambuco, nem preciso lhe dizer, eram todos usineiros. A exceção que Vargas fez foi pegar um sujeito do sertão e colocar como interventor. Aí a política pernambucana começou a mudar.

Marcelo: Isso não está mudando muito rapidamente? No nordeste há uma febre de empreendedorismo. Chico: Está, muito rapidamente. Você não faria hoje outra SUDENE. Não tem convergência de posições. Flávio: No texto de Elegia para uma re(li)gião, você explica que seu conceito de região é econômico, 
sobretudo. Haveria uma área diferenciada de economia dentro do território nacional, mas aquela fronteira iria se dissolver. Você já percebia isso em 1977. Então, o que você acha de a SUDENE retomar, hoje, essa discussão do Nordeste como região econômica?

Chico: Não faz sentido nenhum, não consegue, não tem força política.

Marcelo: Eles já estão integrados completamente, nacional e internacionalmente?

Chico: Nacional e internacional. Geisel colocou uma pá de cal nesse projeto regional quando acionou a Petrobrás para fazer aquelas empresas mistas no polo petroquímico. A Bahia não tem o menor interesse em se integrar com nada no Nordeste. Então, não tem sentido, economicamente. Há uma região sim, que se diferencia no estilo de vida, na fala, em certos costumes. A cultura popular, que é muito marcadamente diferente da do Sul. A marca distintiva está na cultura popular. Você tem festividades que, no Nordeste, ainda são muito arcaicas. Elas são portuguesas, na verdade. E que vão sendo consumidas pela dinâmica capitalista. Marcelo: Entram na onda da cultura de massa? Chico: Sim. Não resistem como uma manifestação cultural.

Flávio: Em A noiva da revolução, que é um relato pessoal sobre Recife e que foi publicado com a reedição de Elegia para uma re(li)gião, você vai mais nessa, quer dizer, me dou por satisfeito.

Marcelo: Mas ele já não era uma crítica a isso?

Chico: Já era. Agora não tem nada a rever em relação a Elegia para uma re(li)gião. Ele é um texto de despedida: aqui a questão regional acabou.

Marcelo: Essa é a ideia que você defende hoje, que estava indicada com aquele acerto de contas. Então, é um texto que tem atualidade, que está dizendo que aquilo acabou. Não é o objeto que é atual, mas a análise crítica que você faz.

Chico: O nordeste que eu prezo é o da memória, não mais o da estrutura social da forma pela qual o sistema desenvolveu lá. $\mathrm{O}$ ajuste de contas já foi feito.

Flávio: Mas você volta ao tema em O elo perdido, ao analisar a Bahia, especificamente. É um texto que tem muita semelhança com a temática de Elegia para uma re(li)gião, essa ideia de um processo de reprodução do capital que se dá fora e a dificuldade de você ter uma representatividade de classe.

Chico: A Bahia, com o impulso dos anos 1970 e 80, descola-se completamente. Com uma contradição: esse processo é tão violento e tão rápido, que você não vê Salvador como uma cidade operária. Ela não tem nenhuma marca de cidade operária. E foi! No passado lá, remoto, era uma cidade operária. Não tem mais nenhuma marca. O processo foi de uma ruptura extremamente violenta. Meu texto não dá conta disso, ele é fraco. Eu deveria ter sido mais incisivo na análise dessa ruptura, mas é uma ruptura violenta. Salvador transformouse na Meca de todos os desejos brasileiros. Ela não tem a marca da cidade operária. E era, até os anos 1940, fortemente operária.

Marcelo: Na Bahia, você era criticado por não ver uma tradição operária em Salvador. Naquele texto, você que diz que a Petrobrás chegou e construiu uma classe operária nos anos 1950, mas que antes não havia essa tradição. E eles diziam: "o Chico está ignorando que havia uma cidade operária antes, uma Salvador operária, que não aparece no texto dele".

Chico: É, não aparece, de fato. Eu dei pouca relevância a isso. E até dei pouca relevância à violenta ruptura. A Petrobrás, na verdade, instaura uma 
ruptura definitiva, e aí essa cidade operária submergiu. Mas pouco interessa hoje. Você vê Salvador como a Meca de todos os nossos desejos refreados e a Petrobrás. Ela nunca foi muito marcada como uma cidade operária.

Marcelo: Ao contrário de Recife?

Chico: Ao contrário de Recife, cuja história você só entende pela história da classe operária. Se não, se não for por aí, você não entende nada. Salvador não tem essa marca distintiva. Embora, evidentemente, todo baiano se levante às três horas para trabalhar (risos).

Marcelo: É a questão do "outro". Não tem um outro demarcado como o inimigo de classe?

Chico: Não tem. Em Recife tem. Em Recife, a demarcação era formidável, a começar pela experiência de convívio com as minhas empregadas domésticas na infância. De onde que você pensa que política não passava pela cabeça delas? Passava sim. Não havia jeito de votarem em usineiro. Porque elas vinham exatamente da zona da mata de Pernambuco. A zona da mata tem enclaves de pequena propriedade. A gente pensa que é tudo homogêneo, mas não é. Tem enclaves de pequena propriedade e enclaves de economia de subsistência. Daí elas tiravam a experiência da resistência. Elas não nomeavam assim, mas um candidato usineiro não passava. De modo que, se você tomar a história do estado, não há um só governador usineiro no estado depois de 1930. Até antes de 30, eles davam de baraço e cutelo. Depois, não há um só caso.

Marcelo: Mas o próprio Miguel Arraes se aliou, em certos momentos, com usineiros, não?

Chico: Se aliou, o Arraes se aliou. A primeira mulher dele era de uma oligarquia açucareira, Célia de Souza Leão, que é um nome tradicionalíssimo. Um nome tão tradicional, que dá nome ao bolo tipicamente pernambucano. Mas por que Arraes se casa assim? Porque era funcionário do Instituto do Açúcar e do Álcool. Então, ele entra na oligarquia açucareira por essa via do casamento.

Marcelo: Mas ele não era considerado um governador, digamos, oligárquico. Ao contrário.

Chico: Não. Ele começou como prefeito de Recife e foi o partidão que o elegeu. Depois é que ele passou para o nível estadual.

Marcelo: Fazendo outras costuras políticas também, até para ampliar e conseguir se eleger.

Chico: Fez, mas fez, sobretudo, com o pessoal do sertão. Com o pessoal da zona da mata não tinha acordo. Ele era fortemente discriminado, embora houvesse uma relação por via do primeiro casamento.

Flávio: Voltando para Elegia para uma re(li)gião: no mesmo ano, você publicou outro livro, o A Economia da dependência imperfeita[(1980)]. A impressão que eu tenho, estudando sua trajetória, é de que esse é um texto que fica um pouco mais esquecido. Ele reúne vários artigos. Há ali uma tentativa de retomar a história da formação econômica do Brasil, que parece mais próxima com a linha do CEBRAP, e há até um texto sobre demografia. Queria que você comentasse um pouco sobre esse livro e o porquê de haver um texto de demografia ali. Era uma questão com o CEBRAP, da interdisciplinaridade? Qual era a ideia daquele livro?

Chico: Aquele livro é o patinho feio, eu não gosto dele (risos). Eu não o faria de novo, mas ele tem duas coisas. A primeira é uma tentativa de entender a formação do capitalismo brasileiro já no nível da formação dos oligopólios, o que muda a luta de classes de patamar. A segunda é esse texto sobre demografia, que é um diálogo com Elza Berquó, que era a demógrafa do CEBRAP. Naquele ambiente, que era muito estimulante, eu travei um diálogo com ela porque os demógrafos, em geral, não têm nenhuma teoria. A demografia é uma ciência sem teoria. Eles são muito pobres do ponto de vista teórico. E eu quis espicaçar, tentando entender exatamente a produção da população sob a necessidade do capital. Mas é um texto mal sucedido. Ele não teve nenhuma repercussão. Os demógrafos brasileiros, em geral, são muito mal formados. Por exemplo, na nossa FFLCH [Faculdade de Filosofia, Letras e Ciências Humanas da USP], quem ensina demografia?

Marcelo: Não sei, na UNICAMP, eu sei que se ensina. O pessoal é forte, sobretudo, em apontar tendências estatísticas, e os economistas e os sociólo- 
gos analisam os dados que eles levantam.

Chico: E só. Assim é no resto do Brasil, devido à forte dominância do IBGE. Quem faz demografia no Brasil é o pessoal do IBGE e eles são muito fracos teoricamente. Competentes do ponto de vista da análise de dados, do domínio deles, dos modelos. Eles sabem projetar de uma forma que o resultado, lá no futuro, vai ser muito próximo. Mas, teoricamente, são muito fracos. Foi uma tentativa de fazer esse diálogo, mas não deu certo (risos). A Elza Berquó nunca entendeu aquele texto. Ela não conhecia Giorgio Mortara, que foi um italiano que o Brasil importou exatamente para fazer o censo de 1940, que é o melhor censo brasileiro. Mortara era um italiano fascista que veio bater aqui (risos). Eu falei para ela do Mortara, e ela não sabia quem era. A gente sabia porque tinha um texto pela via da CEPAL. Mas aquele meu texto é mal sucedido. Flávio: Pouco depois, você entrou na PUC, em 1978, para o departamento os estudos pós-graduados em economia. Mas aí você entra como economista, você ainda era visto como um economista, tanto dentro do CEBRAP quanto fora, sempre com essa imagem.

Chico: Aquilo foi um arranjo (risos), ninguém levava muito a sério. A PUC estava num processo de mudança. Na área de economia, eles tinham convidado Paul Singer, Walter Barelli. Eles estavam num processo de mudança na pós-graduação de economia, que era muito frágil. Eu entrei nessa onda, e aí não fizeram muita distinção se você era economista ou não. Mas a PUC não me deu nada, só salário, que é importante (risos).

Flávio: Já tinha ocorrido uma reestruturação das universidades no Brasil, a ideia de uma carreira acadêmica já estava se abrindo de uma forma mais clara para esse pessoal. Mesmo no CEBRAP, cada um tentava seguir seu caminho de carreira acadêmica. Então, a PUC também era uma alternativa, uma opção para sustentar o trabalho intelectual. Chico: É, mas não me deu nada. Sem nenhuma mágoa, não me deu nada. Não havia ambiente intelectual propriamente na PUC. Era um curso mambembe, que foi sendo reformulado assim, aos trancos e barrancos. Eles convidaram Paul Singer, que foi para lá, ficou uns dois anos. Octavio Ianni estava.

Marcelo: O próprio Florestan deu aula lá, não?

Chico: Deu. Octavio deu aula nas ciências sociais. Marcelo: Maurício Tragtenberg?

Chico: Sim. Eles convidaram também Walter Barelli, na economia, Ademar Sato. Eu entrei por aí. Mas não havia nenhum ambiente intelectual.

Flávio: Foi nessa época, 1982, que você foi para a França fazer o pós-doutorado. Queria que você falasse sobre essa experiência. Você ficou lá dois anos, ou foi uma coisa mais rápida? Teve o apoio da PUC?

Chico: Não, a PUC nem pagar meu salário pagou. Eu queria ter uma experiência universitária internacional, mas não valeu a pena. Fora Paris, que vale bem uma missa (risos), não valeu a pena. $\mathrm{O}$ ambiente universitário francês é extremamente fechado. Eu não tenho experiência de outros locais, mas acho que o americano deve ser mais aberto. $\mathrm{O}$ francês é extremamente fechado. Eles não te reconhecem. Eu não fiz nada relevante na França, a não ser curtir Paris e ler bastante.

Marcelo: Você preparou lá O elo perdido?

Chico: Preparei lá, onde fiquei quase dois anos. Eu fui com a cara e a coragem. Fernando Henrique, que naquela época ainda era muito generoso, me indicou para uma bolsa na OCDE. Eu ganhei essa bolsa e depois pedi outra ao CNPq. Essa bolsa do CNPq foi negada, e aí eu fiz uma carta desaforada para o Marcos Formiga, que era o superintendente do CNPq. Eu listei o que eu tinha feito e disse: "Se você ainda acha que eu não tenho direito à bolsa, negue!”. Aí eles me deram e eu aproveitei Paris. Mas intelectualmente, não. A coisa que eu comecei a escrever lá foi por sugestão do Fernando Henrique. O intercâmbio com a universidade francesa é extremamente difícil. Você não entra. Há certas instituições onde os requisitos de entrada são menores. Não no Collège de France, que só lhe serve para você assistir conferência.

Marcelo: Você tem menos interlocução lá, mas, pelo menos, se ouve o que eles falam, não é?

Chico: Ouve o que eles falam, mas você não fala. E, se você falar, eles não ouvem, porque eles são 
surdos. A França ainda tem resquícios da antiga glória intelectual. É muito difícil. Você vê, mesmo um tipo como o Roberto Schwarz, que dá banho em qualquer crítico literário francês, ele não tem boas recordações da França do ponto de vista de intercâmbio intelectual. É extremamente difícil. Valeu a pena, porque Paris vale bem uma missa (risos).

Marcelo: Você diz que a passagem pela PUC não agregou muito à sua trajetória, e essa estada na França agregou, mesmo sem essa interlocução?

Chico: Agregou por isso, porque eu comecei a tentar aquilo que veio a ser a marca da minha produção pós Crítica à razão dualista. Foi ali que eu comecei a tentar entender os problemas do capitalismo desenvolvido. Agora, isso sem nenhuma interlocução.

Marcelo: Eu acho que você ficou impactado com o Estado de bem-estar social e começou a fazer suas reflexões sobre o antivalor. Eu imagino que tenha sido muito forte sua experiência de morar lá e de ver uma realidade completamente diferente.

Chico: Foi isso. Não foi, portanto, um intercâmbio intelectual com a universidade francesa, mas foi esse impacto do Estado de bem-estar. A questão dos direitos dos trabalhadores e desse Estado de bem-estar, que é, na maioria das interpretações, visto como uma concessão. Eu tentei revirar a página, quer dizer: isso tudo é produto de uma luta de classes histórica, acumulação. Foi um impacto, e você precisa estar aberto para entender as novas experiências. Eu via alguns amigos meus lá, brasileiros, que tiravam o que podiam do Estado francês. Eu não tirava porque eu era acanhado. Até férias eles tiravam. Aquilo realmente me impactou. Foi uma visão completamente nova, e eu comecei a prestar atenção.

Flávio: Essa experiência influenciou quando você voltou o Brasil, em 1984, com a questão da transição democrática, e o PT já tendo uma importância no cenário nacional. Dessa época, eu destaco três artigos seus. O primeiro chamado "Além da transição, aquém da imaginação", no qual você discute como estava ocorrendo o processo de transição no Brasil, os arranjos de poder. O segundo é um arti- go sobre o PT, no qual você fala um pouco de como o partido propunha uma ruptura muito forte com a tradição da esquerda no Brasil, que resultava num anticomunismo. O último é "As aves da arribação", em que você comenta sobre as mudanças dos intelectuais no Brasil.

Marcelo: Acho que tem mais um, aquele da "Medusa ou as classes médias" [(OLIVEIRA, 1988, p. 282)], em que você trabalha com a ideia das classes que gerem o fundo público.

Chico: Eu não posso falar muito, porque eu não lembro muito bem deles. Esse último foi um diálogo muito interessante com Guilhermo O’Donnell. Guilhermo era um weberiano tout court, mas ele era muito aberto. Então, eu aproveitei aquela experiência na França e entrei por aquela via no artigo. Dos outros artigos, sobretudo esse sobre o PT: eu achava que o PT tinha tudo para ser um partido social-democrata. O que os outros consideravam uma ofensa eu achava um elogio.

Marcelo: No bom sentido de social-democrata? Flávio: A partir da imagem que você trazia da França? Chico: Sob a influência e do que eu tinha visto do Estado de bem-estar.

Flávio: Você achava que o partido deveria ter um papel civilizatório dentro do capitalismo, que é o que você sempre fala? A esquerda tem que ter este papel civilizatório, e já seria alguma coisa se o PT conseguisse ter.

Chico: Já seria alguma coisa. Então, aquele artigo sobre o PT é basicamente isso, mas o sindicalismo foi mais forte e transformou o PT nisso que ele é hoje. Tem dois grandes grupos de gangues no Brasil, não tem classes aqui. Tem gangues. Os de baixo estão organizados como gangues e os de cima também. Os de cima assaltam o tesouro público. Eike Batista é o exemplo mais à mão. Os de baixo assaltam-se uns aos outros. Daí que as transformações brasileiras estão sendo impostas de fora para dentro, não no sentido de retomar o velho papel do imperialismo, que, aliás, é extremamente forte, mas no sentido de que se você entrou na corrida do capitalismo oligopolista, não tem volta mais. Você tem uma compulsão a copiar os modelos. A luta de classes, como processo da política, foi pro 
espaço. Essa era a minha esperança quanto ao PT. Flávio: Sua postura nos anos 1990 foi essa? Aquela aposta nas câmaras setoriais era um pouco com essa linha: não se tinha uma esperança de que aquilo poderia levar a uma revolução, mas poderia resultar numa ampliação da democracia no Brasil?

Chico: Era isso, enfim. Era uma proposta socialdemocrata kautskiana. Mas não deu. O capitalismo varre tudo pela frente. Então, não há direitos nem força política capaz de deter essa marcha acelerada. Foi uma aposta equivocada.

Flávio: Qual era a situação ali, no final dos anos 1980, dentro do CEBRAP? Eu li um artigo do Rodrigo Naves [(2006)] em que ele conta que, àquela altura, ele já sentia que o CEBRAP não era mais aquele dos anos 1970. Era cada um por si, ninguém preocupado em pensar grandes questões, a coisa já tinha mudado muito. Qual é a sua opinião? Qual era a situação do CEBRAP?

Chico: A situação do CEBRAP era assim: ele ganhou muito prestígio externo, passou a ser uma referência, e isso entrou lá dentro de forma bastante danosa. Em primeiro lugar, afastaram-se vários dos fundadores. O Fernando Henrique foi para a política e nunca mais voltou. OChico Weffort saiu, fundou o CEDEC, e também nunca mais voltou. O Bolívar Lamounier, que era uma voz dissidente, sempre, também saiu, fundou o IDESP e não voltou mais. O Octavio [Ianni] saiu por outras razões. era um grande intelectual, e eu, porque todos os outros que podiam ter esse papel já tinham saído. Eu comecei a, involuntariamente, articular um grupo de mais jovens, de gente que estudava Marx. Na verdade, foi isso, foi uma disputa de liderança intelectual. E o Giannotti usou de todos os golpes baixos possíveis, até que, em 1995, eu saí. Porque não dava mais, não tinha mais razão. De 1992 ou 93 até 95, eu exerci a presidência, mas foi um mandato tampão, de conveniência, e depois disso eu peguei o chapéu e fui embora.

Marcelo: E isso tem a ver também com a história da presidência da república, com o fato de o Fernando Henrique ter sido eleito?

Chico: Tem. Eles não admitiam - o Giannotti, a Elza Berquó - que alguém do CEBRAP, que tinha convivido com o Fernando Henrique, não votasse nele. E aí se abriu um conflito, ficou aberto. E foi uma fase péssima do Giannotti, porque ele assumiu um antimarxismo militante, que não é o caso dele. Ele conhece bem Marx, muito melhor do que eu. O Fernando Henrique já estava fora, em 1995, então a luta, que era surda e bastante encoberta, ficou descarada. E o Giannotti tomou a si a tarefa de expulsar o grupo marxista do CEBRAP. Era um grupo que eu coordenava não como grupo, coordenava intelectualmente. Fazia discussões. Estávamos eu, o Adalberto Cardoso, o Álvaro Comin, que está na Inglaterra.

Flávio: O estudo sobre as câmaras setoriais foi feito dentro do CEBRAP, por esse grupo?

Chico: Foi esse grupo. Esse grupo foi articulado involuntariamente, ninguém estava querendo fazer grupo nenhum. Mas, no fundo, tratava-se de disputar quem dava a diretriz intelectual.

Marcelo: E é curioso, porque o Giannotti constituiu a legitimidade intelectual dele, em grande parte, como articulador daquele grupo do Capital, como você mesmo falou no começo da entrevista. Uma pessoa com grande domínio da dialética.

Chico: Sim. Aquilo era político no fundo, não é? Ele assumiu aquela posição para expulsar todos que ele chamou de marxistas do CEBRAP. Como eu sou muito irreverente, eu disse: "Então você se autoexpulsa, Giannotti” (risos). Ele nunca gostou. 
O senso de humor dele é curto. Aí colocaram o Vilmar Faria na presidência. À Elza Berquó eles nunca entregaram a presidência, porque ela não tinha prestígio nas ciências sociais. Essa era a razão básica, eu acho. A não ser que tinha alguma razão que eu não entendi. Então deram ao Vilmar Faria a presidência, e ele não exerceu completamente, porque foi quando o Fernando o chamou para Brasília. Eu fiquei com o mandato tampão de dois anos e, em 1995, eu peguei o chapéu e fui embora.

Flávio: Você estava na USP já desde 1988?

Chico: Eu estava na USP.

Marcelo: E a USP trouxe coisas para você? Diferente da PUC?

Chico: A PUC não foi nada, não tinha um ambiente intelectual. Você ia lá dar aula e acabou. A USP não. Na USP, eu caí num grupo muito interessante, que é um grupo ao qual eu pertenço ainda de forma bastante lateral, mas felizmente caí num grupo liderado pela Maria Célia Paoli, e a gente formou um núcleo de estudos, que depois foi transformado em centro. Aí foi uma experiência, desde então, muito boa.

Flávio: O CENEDIC [Centro de Estudos dos Direitos da Cidadania] foi fundado em 1995-96, logo depois que você saiu do CEBRAP? E quem idealizou? Você ou a Paoli?

Chico: Foi a Paoli. Ela tinha um grupo de gente que ela orientou, de mestrado e doutorado, ao qual eu me agreguei. Tinha a Beth Lobo. É um grupo muito interessante. Tinha o Laymert Garcia, que hoje está afastado.

Flávio: Mas esse grupo foi fundado em 1995-96 e você já estava na USP desde 1988. Esse período de sete anos, entre a entrada na USP e a formação desse grupo, como você avalia? Foi uma experiência boa? Já tinha contato com essas pessoas, mas não tinha formalizado o grupo?

Chico: O grupo existia, mas não formalizado. Era um conjunto de pessoas.

Marcelo: Sua referência não seria ainda especialmente o CEBRAP até esse começo dos anos 1990? Você ficou um tempo nas duas instituições, talvez o CEBRAP no começo ainda pesasse mais?

Chico: Não, não pesava não. $\mathrm{O}$ problema do
CEBRAP foi conveniência. Eu disse: “Giannotti, eu vou continuar aqui e você me paga o meu salário e não tem direito de exigir nada”. Então, eu fiquei até 1995 lá, quando eu peguei o chapéu e fui embora. E aí a convivência já era quase agressiva. Mas agora mudou, faz anos que está macio de novo.

Marcelo: Você não disputa mais nada com ele.

Chico: Eu não disputo mais nada com ele, ele se sentiu seguro. Também o CEBRAP transformouse numa instituição de pesquisa convencional. Não é que eles não fazem mais pesquisa, fazem. Mas é muito convencional, muito ortodoxa.

Marcelo: E aquela discussão sobre o antivalor, foi sua tese de professor titular?

Chico: Foi, mas não tem tese não. Foi uma aula que eu dei.

Marcelo: Mas é um pouco o que você juntou depois no livro da Editora Vozes? [(Oliveira, 1998)]

Chico: Foi a aula que eu dei. Isso estava sendo gestado lá na França. Naqueles anos, de 1982 a 84. Flávio: Foi polêmico quando ele saiu? Pelo menos até hoje eu sinto isso. Eu sou mais recente, fiz a graduação em 2003 na USP, mas, quando falam desse texto dentro da USP, alguns marxistas mais ortodoxos ficam com o pé atrás. Como foi a recepção desse texto do antivalor?

Chico: Fraca. Justamente os marxistas mais ortodoxos nunca o entenderam. Aliás, os marxistas mais ortodoxos são um pé no saco (risos). O marxismo no Brasil, quem estuda bem é o Bernardo Ricúpero, é uma coisa estranha, porque o Brasil moderno você não entende sem o Partido Comunista. Mas, no que deveria ser específico do Partido Comunista, que seria desenvolver uma teoria marxista sobre o Brasil, ele falhou. Em tudo mais, a presença dos comunistas é notável. Você não tem arte brasileira, cinema brasileiro, literatura brasileira, sem os comunistas. Mas, no específico da teoria política, o Partido Comunista é um fracasso formidável (risos). Depois da tentativa de Nelson Werneck Sodré, que nós apreciamos muito, mas conhecemos as limitações dela, não há uma só contribuição que valha a pena. Daí a enorme dificuldade que eles têm em dialogar com alguém que não se coloca no campo da ortodoxia. 
Marcelo: Pulando um pouco: quando você rompeu com o PT, esse pessoal deu suporte. A turma do PSOL e certa esquerda marxista mais ortodoxa - diante da qual você sempre apresentou algum ou muito distanciamento ao longo da vida - de alguma maneira te adotou, digamos assim, para criticar o governo Lula. Porque você consegue fazer uma formulação marxista, talvez a mais consistente, para criticar o governo Lula. Hoje você tem uma convivência como esses velhos adversários mais ou menos reconciliada?

Chico: Não sei te dizer, Marcelo, porque eu acho que o PSOL é um fracasso. Eu entrei na do PSOL, numa tentativa de fazer uma crítica ao PT pela esquerda, já que a crítica pela direita estava aí. Mas quem faz o PSOL, na verdade, pensa que pode refazer o caminho do PT. Então, não entenderam nada. Em geral, a esquerda brasileira tem uma enorme dificuldade de entender as transformações. Ela trata o capitalismo brasileiro de hoje como se fosse o dos anos 1950. Tem uma enorme dificuldade. O PSOL foi essa tentativa, que até onde eu posso avaliar fracassou, porque a crítica que eles fazem é de que o PT fracassou porque não foi suficientemente radical. Então, como acontece em toda formação partidária, a técnica é antiga: você se apropria dos espaços institucionais do partido e aí morreu. O que tem de novo no PSOL, realmente? Nada. Assim como o PT já havia falhado, porque o PT não tem uma teoria sobre o Brasil, seguindo as trilhas do próprio Partidão, o PSOL vai no mesmo caminho. Eles não têm uma teoria sobre o Brasil hoje. Assim como o PT não teve.

Marcelo: Esse negócio de faltar uma teoria não tem um viés leninista? Quer dizer, a prática política seria outra se houvesse alguém iluminado no partido que escrevesse nosso Desenvolvimento do capitalismo na Rússia. Não tem essa coisa?

Chico: Tem. Aliás, a primeira observação minha é sobre o próprio Lênin. Observando o México, ele dizia que o México tinha feito uma revolução sem teoria. Daí o impasse em que entrara. Evidentemente, isso é supervalorizar o papel de uma teoria. Mas o que eu estou chamando teoria não é propriamente um texto escrito. É uma visão e uma concepção da nova nação. O partidão falhou nisso, o PT falhou nisso, e a esquerda continua falhando. Todos eles imaginam, ainda, um capitalismo quase imóvel, como se não houvesse transformações. As transformações são muito poderosas. $E$ a esquerda tem uma enorme dificuldade de entender esses processos. Não deveria ter.

Marcelo: Não é só a brasileira.

Chico: Não é só a brasileira, a esquerda tem uma enorme dificuldade de entender o caráter das transformações. Para onde elas apontam, quais são as oportunidades que ela cria e quais são as oportunidades que ela esmaga. O PSOL também está nessa, quer dizer, o PSOL pensa que o PT fracassou porque não foi suficientemente radical.

Flávio: Eu queria só explorar um pouco mais a história do CENEDIC antes de chegar nesses últimos 10 anos. Sobre o CENEDIC, que, na época, ainda era NEDIC, você acha que ele conseguia resgatar um pouco, no início dele, acho que até hoje talvez, aquele formato de debate mais franco, mais aberto, sem mediações que você falou que tinha o CEBRAP nos anos 1970? Isso fazia parte do projeto de vocês quando fundaram o NEDIC? Fazer um espaço de debate multidisciplinar e bem aberto? Chico: É bem aberto, mas ele é pequeno. Não tem a relevância que o CEBRAP tinha nos anos 70, e ele não é aceito dentro da USP. O Departamento de Sociologia, que é nossa âncora principal, acha que é um bando de porra-louca reunido. Então, ele não tem nem a importância nem a relevância que o CEBRAP teve.

Marcelo: É que a lógica da universidade é constituir pequenos grupos fragmentados. Tem outros como ele, que é mais um a conviver com os demais.

Chico: Ele é um que convive. Então ele não é nem prestigiado nem discriminado.

Flávio: Como se ele fosse independente, paralelo ao departamento?

Chico: Não, o departamento é a âncora principal dele. Porque todos os que formaram primeiro o NEDIC, depois o Centro, são, de alguma maneira, originados do departamento de sociologia. Agora é que o André [Singer], que é do departamento de 
política, é o coordenador. Mas a Maria Célia [Paoli] é da sociologia, o Leonardo [Mello e Silva] é da sociologia.

Flávio: A Vera Telles?

Chico: A Vera Telles é da sociologia. Eu era da sociologia, agora não. Há mais de 10 anos já estou aposentado. A âncora principal é o departamento, e eles acham que o Centro faz concorrência a eles, ou acham sem importância.

Marcelo: Como é que aconteceu essa sua aproximação, fundada num pensamento marxista heterodoxo, com esse pessoal que vem de uma outra tradição de esquerda, que não é marxista, como no caso da Maria Célia Paoli?

Flávio: Nessa época, ocorreu a entrada das ideias do Jacques Rancière [(1996)], que acho que foi o nome que norteou aquela pesquisa do NEDIC, que depois resultou naquele livro que você e a Paoli organizaram, Os sentidos da democracia. Queria que você falasse um pouco sobre como foi esse casamento de perspectivas diferentes e por onde $o$ Rancière entrou aí, se foi a Paoli que trouxe ou você, da França?[(Oliveira; Paoli, 200)]

Chico: Eu acho que fui eu quem trouxe o Rancière. A relação foi, em primeiro lugar, afetiva. Eu acho que nós nem percebíamos as diferenças entre a minha posição e a dela. Com a convivência, isso foi aparecendo, mas, no princípio, foi uma aproximação afetiva. Ao longo do desenvolvimento de que resultou o NEDIC e depois o CENEDIC. Hoje ela está bastante afastada, mas ela participava das coisas. A gente poliu as arestas. Eu insisti muito para a posição heterodoxa, até me chamavam de prussiano (risos). Eles nem suspeitam o quanto eu detesto a Prússia (risos). Mas eu encontrei muita afinidade com o Laymert [Garcia dos Santos], que não é nem um marxista ortodoxo, nem se considera. Mas ele é muito aberto. E a gente foi polindo as arestas, ao mesmo tempo em que eu valorizava os temas que ela trazia. Devo confessar que minha releitura do Gilberto Freyre foi muito influenciada pela Maria Célia.

Marcelo: Você tinha um preconceito maior em relação a ele?

Chico: Gilberto, no período em que fiz universida- de no Recife, era pecado mortal. Porque ele já tinha passado para a direita e ele era hostilizado abertamente nas bancas de concurso. Então, eu vim reler Gilberto Freyre influenciado por Maria Célia. E foi essa a aproximação que a gente foi tecendo. Eu sou muito grato a ela, enfim.

Marcelo: Talvez porque elas valorizam muito a questão do republicanismo, dos direitos, e você trazia esse debate por outra via, com a questão do antivalor, da construção dos direitos, que não é uma concessão, mas fruto de uma história passada. Vem desde a Revolução Francesa, num processo longo. Talvez tenha havido aí um casamento de aproximação social democrata, no bom sentido, da ampliação dos direitos.

Flávio: Que era o grande tema dessa pesquisa inspirada no Rancière. Até no nome do NEDIC tem tudo a ver: Núcleo de Estudos dos Direitos da Cidadania.

Chico: É, foi sugestão dela. Faz anos que ela já se afastou. Ela estava muito ativa e foi muito importante. Um grupo que não era nada formal nem organizado, mas ele só se organizou porque a reitoria disse que era melhor se organizar. Íamos nos beneficiar de alguma coisa que a reitoria poderia dar. E depois nos transformamos em centro, porque o diretor da faculdade nos chamou e aconselhou a transformar em centro. O Francis Aubert, da área de letras, disse: "Vocês como centro eu posso dar recursos. Como núcleo eu não posso, porque núcleo é ligado à reitoria”. Então, a gente se transformou em centro. Foi tudo uma coisa de conveniência bem sucedida. Mas a Maria Célia era muito importante e ela teve esse papel de aparar as arestas dos prussianos (risos) em relação à questão da democracia, dos direitos. Eu vinha pelo outro lado e tentando mostrar, da minha maneira, como a luta de classes produzia esses resultados. Flávio: Em dois textos seus do final dos anos 1990, "Apocalipse Now", que foi a introdução ao relatório final do estudo sobre o acordo das montadoras, e no texto que está nesse livro sobre Os sentidos da democracia, sobre o totalitarismo neoliberal, aparece uma mudança de perspectiva sua, como quem diz "essa nossa aposta nos valores republicanos 
não vai mais dar, já está ultrapassada, não tem como seguir levantando essa bandeira". A ideia é de que o neoliberalismo atropelou tudo isso, todas as possibilidades. Como, por exemplo, o acordo das montadoras. O Rancière deixa de ser referência aí? Ele é citado no texto, mas eu sinto que já tem certo distanciamento.

Chico: Eu acho que é isso. Meu pessimismo está mais amargo do que nunca (risos). A história é assim, você vê: a forma da produção e reprodução no Brasil não tem mais o que acrescentar. Quer dizer: os arcaísmos foram todos derrotados, não dá. Você está num modo de produção e reprodução nitidamente capitalista.

Marcelo: Mesmo que sobreviva se alimentando do "arcaico", entre aspas.

Chico: Mesmo que sobreviva. Mas isso faz com que você não possa percorrer a trajetória que a social-democracia percorreu. Você está compulsivamente obrigado a copiar os países desenvolvidos. Quer dizer, a autonomia do capital no Brasil é tal, que o progressivo crescimento dos direitos e sua implementação estão fora do horizonte.

Marcelo: Você acha que tudo que tem sido feito é mais dádiva, organização do Estado, do que construção de direitos?

Chico: É mais organização do Estado, administração de carências, do que conquista de direitos.

Marcelo: Isso é que me deixa com um pouco de dúvida. Você cita a experiência da classe trabalhadora europeia, que é muito mais densa e mais secular, que redundou no Estado de bem-estar social. Houve lutas expressivas na sociedade brasileira, particularmente na resistência à ditadura. E o PT encarnou isso. Não deu nem numa revolução nem em reformas de fundo social democráticas, mas deu em alguma transformação, que talvez não seja o que a gente gostaria que tivesse sido, mas que, a seu modo, também carrega essa experiência social. Houve uma construção coletiva, não só do PT. Um processo histórico que desembocou não numa consciência revolucionária, nem, digamos assim, nos direitos, no sentido do Estado de bemestar social. Mas a sociedade se moveu e há algum rearranjo que é, claro, muito mais interessante para o capital, mas que atinge também uma parcela significativa da população. Quando vou ao Nordeste, conversando com as pessoas de lá, é onde mais se sente isso. Talvez essa ideia da colonização da política pela economia, que você desenvolve e acho muito interessante, permita pouca possibilidade de ruptura do ponto de vista do modo de produção, seja no sentido revolucionário ou reformista, mas não significa que não haja possibilidade para alguma ação política transformadora dentro dos limites do capitalismo. Tanto que tem a Cristina Kirschner na Argentina, o Hugo Chávez na Venezuela. Tem ainda Equador, Uruguai... De alguma maneira, a esquerda encontra o seu jeito. Se olhar do lado cético, você vai dizer "todos estão perfeitamente enquadrados na lógica do capitalismo internacional". Mas são experiências diferentes que expressam uma mudança social. Por isso eu não consigo ser tão pessimista como você. Estou tentando espicaçar pra ver alguma luz, alguma possibilidade dentro desse universo que fica quase sem saída.

Chico: Não, vejam bem, eu não sou um pessimista de profissão (risos). Você citou todos esses países. O único que está empacado é justamente o Brasil, onde não se passa nada de novo. Quer dizer, tudo que você disse é verdade, mas tudo isso é produzido pelo desenvolvimento do capitalismo. Cada vez que você lê um livro fica influenciado por ele. Eu estou terminando a leitura de um livro sobre o imperialismo norte-americano.

Marcelo: Que alguns dizem que não existe mais... Chico: Esse livro é datado, ele já tem uns quinze anos. Você percebe que a trajetória do capitalismo norte-americano foi tão bárbara quanto a nossa. É de um sujeito chamado Kiernan [(2009)]: Estados Unidos: o novo imperialismo. O que houve de barbaridade ali. Eles extinguiram as nações indígenas, algumas delas já tinham alfabeto! Eles extinguiram, quer dizer, os espanhóis são tidos como os colonizadores cruéis. Os Estados Unidos foram mais cruéis do que os espanhóis, internamente. Então aí talvez seja esse período que a gente está passando e, daqui para a frente, as coisas vão melhorar. Aí vem o meu ceticismo: não é à toa que 
você se converte na sexta ou quinta economia capitalista do mundo, isso não é à toa. Isso tem um preço extraordinário. Eu estou fazendo um pequeno texto que eu vou discutir no grupo do Renato Martins, que é o "Pequeno Napoleão", que é o Lula, evidentemente. Qual é a lição que se extrai do Napoleão? Napoleão exportou a Revolução Francesa para o resto da Europa e, internamente, foi o regime mais repressor, quer dizer, anulou todas as conquistas da Revolução Francesa. Lula é um pequeno Napoleão. O que é que o PT fez esses anos? Fernando Henrique é outra coisa. Todo mundo gosta de falar mal do Fernando Henrique. Eu não falo mal. Fernando Henrique acreditou no sonho burguês de regulamentar o capitalismo. Então, ele criou as agências, ANVISA, ANATEL, etc.. Neste caso, o político desaprendeu o que o sociólogo sabia. Ele tentou regulamentar, disse: "Aqui o capitalismo tem que crescer dentro desses parâmetros, seguindo uma ordem burguesa, previsível”. Até por isso ele não conseguiu, não só por espírito de classe. Ele é, de fato, elitista (risos), mas pela forma da reforma do Estado que ele tentou implementar. Qual foi a reforma do Estado que o lulismo fez? Nenhuma. Nenhuma! Não há nada na estrutura do Estado republicano brasileiro que tenha sido acrescentado pelo lulismo. Aliás, o termo lulismo é do André Singer [(2009)]. Aí, o quê o PT fez? O PT fez foi desembaraçar: "abre alas", que é para poder o processo avançar sem regulamentação nenhuma. Converteu-se na sexta economia mundial e não tem mais capacidade de refazer o caminho que a social-democracia fez. Porque você é compulsivamente obrigado a seguir todas as novas tendências, se não você fica para trás. Qual é o segundo país do mundo a utilizar celular? O Brasil. Todo mundo tem celular.

Marcelo: Se você olha da perspectiva dos de baixo, da empregada doméstica, por exemplo, ela tem celular hoje, compra televisão de plasma à prestação. Para alguns, tem a luz elétrica que não chegava. Ou seja, conversando como você conversava com as empregadas domésticas há 40 ou 50 anos atrás, as de hoje também gostam do Lula.

Chico: Eu sei, isso eu sei.
Marcelo: Então, é uma coisa um pouco trágica do ponto de vista socialista, aquilo que você chamou de transformação da classe em pobreza, mas de alguma maneira as satisfaz.

Chico: Não há dúvida, Marcelo.

Flávio:É a questão da inclusão pelo consumo, que o André Singer explorou no texto dele sobre o lulismo. A impressão que dá é que a diferença do Singer para você é que ele acredita que esse processo vai levar a contradições que talvez permitam, daqui a algum tempo, uma rearticulação da política.

Chico: Eu gosto muito do André, por razões muito afetivas. Ele é filho do Paul, que é um grande amigo, para quem eu tenho enorme carinho e gosto muito dele depois que passei a ter uma convivência maior. Ele é hoje o coordenador do CENEDIC. Mas eu não participo de nenhuma das ilusões do André (risos). E acho que ele está vendo miragens. No deserto, você vê miragens (risos). Ele está vendo miragens, além de ser um ponto de vista teoricamente equivocado, e eu me permito dizer que está equivocado. Isso tudo é produto do desenvolvimento do capitalismo: TV de plasma, o celular. Mas, e é claro, elas, as empregadas, têm razão de gostar do Lula, assim como na minha infância elas não gostavam dos usineiros. Aí é que está a maldade. Esse gostar do Lula é a condição para frear as transformações. Transformações da base produtiva não são um bom critério para um marxista. É um paradoxo isso, porque o marxismo virou uma receita de bolo econômica depois da banalização que o marxismo soviético fez. Eu não gosto desse marxismo. Definitivamente, para mim, é o fim da picada. Quer dizer, o marxismo que eu cultivo é aquele em que o poder de classe aumenta e esse poder de classe é que pode dar as novas diretrizes. E a opção do André pelo consumismo não aumenta nenhum poder de classe. Aumenta o poder aquisitivo, mas eu não participo desse otimismo. Eu acho que nós estamos definitivamente, por uma longa e larga conjuntura histórica, enterrados no desenvolvimento capitalista norte-americano avacalhado. Tudo bem, baseado num momento de consumo de massas e tal. 
Não estou contra, devo dizer: a minha ética é cristã. Porque eu fui educado no cristianismo. Meus valores éticos são cristãos, não são marxistas. Eu não posso ser contra a melhoria do consumo das classes populares. Eticamente eu não posso. Poderia até arrolar dezenas de razões econômicas, mas eticamente eu não posso. Como que eu estou de barriga cheia e vou ser contra? Acontece que, e a sociedade norte-americana é a prova disso, esse caminho vai inevitavelmente esbarrar com a opressão de classe. Você não tem como superar isso nesta larga conjuntura histórica que eu não sei medir quantos anos ou décadas são, mas você esbarra. Eu não gosto nem de chamar de sociedade de consumo, porque isso já tem certo preconceito que não consegue se superar. Eu acho que o Brasil está numa larga conjuntura histórica em que não vai superar esses estigmas. E não é porque os benefícios do consumo não chegaram. Ao contrário, é porque os benefícios do consumo chegaram. Eaí, exatamente, se toda empregada doméstica tem um celular, qual é a promessa da revolução?

Flávio: Eu estava num seminário recente do CENEDIC em que houve sua exposição. O CENEDIC agora está se colocando qual será o tema da pesquisa que vai ser feita daqui pra frente, qual vai ser o novo projeto. E você dizia que o grande desafio para o CENEDIC, e para as ciências sociais em geral, é tentar descobrir de onde pode sair essa voz dissonante. Se você não pode mais apostar no operariado tradicional, nesse trabalhador formalizado, de onde é que pode vir esse sopro para a transformação? Queria que você falasse um pouco disso: você acha que é realmente esse o grande desafio hoje, não só para as ciências sociais, mas desafio da esquerda, desafio da política no Brasil, pensar de onde pode sair esse sopro?

Chico: Eu não vejo de onde vai sair. É claro que é por via das ciências sociais que eu formulo as questões que eu tento entender, responder acima da minha capacidade, é por via delas que eu abordo. Eu não vejo que o meu campo científico esteja soprando nada. Não sinto esse sopro. Ao contrário, sinto um sopro de um conformismo dourado.

Marcelo: Enquanto der pra dourar, porque tudo isso envolve a continuidade do crescimento, do desenvolvimento.

Chico: E vai ter, Marcelo.

Marcelo: Parece que o capitalismo tem muito pra avançar no Brasil.

Chico: Tem muito. Não tem fronteira mais do ponto de vista de que existem algumas regiões em que o modo de produção não é pleno. Aí acabou. Mas tem muito para avançar.

Marcelo: Recursos naturais, humanos.

Chico: Humanos, tem muito. Quer dizer: nós temos duzentos milhões de habitantes. São cinco países do mundo com esse recurso. Isso aí é força de trabalho para homem nenhum botar defeito. Evidentemente, só perdemos da China e da Índia. Mas ainda não ocorreu a nenhum maluco, e certamente não vai ocorrer, tentar ultrapassar a China e a Índia. Fernando Henrique tentou, em termos de desregulamentar os direitos do trabalho. Seria uma loucura formidável.

Marcelo: Talvez esse seja o avanço do Lula. Se ele não mudou nada no Estado, ao menos ele barrou a continuidade daquele desmonte da Era Vargas que o Fernando Henrique se propôs a fazer, aumentando o número de carteiras de trabalho assinadas, por exemplo.

Chico: Ele barrou aquele desmonte, mas o preço que ele pagou foi abrir as portas. Numa linguagem mais obscena a gente diria: "manda abrir as pernas” (risos). Quer dizer, tira qualquer obstáculo.

Marcelo: A Walquíria Leão Rego é muito interessada no Bolsa Família, porque gera um dinamismo novo nas comunidades.

Chico: Isso é conversa. Primeiro porque eu não acredito em pesquisa (risos). Como eu sou um sociólogo mal formado, eu não acredito nessas pesquisas que você vai e entrevista a gente. É claro que, se você perguntar a alguém que é beneficiado pelo Bolsa Família, só se ele estiver louco de pedra vai dizer que não gosta. Mas se você seguir outro caminho, que é você desmontar o orçamento família, vai ver quais são os gastos de uma família típica do Bolsa Família. É comprar arroz, se tanto, feijão, farinha, mandioca, a rapadura. Isso é o movimento do capitalismo? Então eu, voltando aos meus 
princípios éticos, eu não posso ser contra. Se eu fosse contra, eu tinha que voltar setenta anos atrás e dizer à minha mãe que não me ensinasse aquelas coisas. Eu não posso ser contra, eu só posso ser a favor. Mas isso move a economia capitalista?

Marcelo: No interior do Nordeste, os dados mostram que tem uma circulação. Enfim, não deve ser praticamente nada, mas você põe algum capital, algum mínimo de dinheiro em circulação, você gera uma circulação. Com uma parte o cara paga a prestação para ter o celular, ou paga a prestação para ter a moto e não precisar do jegue. Enfim, há certa dinamização da economia com esse dinheiro que é injetado, do ponto de vista do capitalismo mesmo. Chico: É tudo feito a velha piada popular: "Não faz onda que é pra poder não passar daqui". Quer dizer, é uma forma de aquietar. Tem um velho amigo meu que, nos tempo do Recife, ia para os comícios desse João Cleontes, que nunca ganhou uma eleição, e começava a dizer desaforo, ali no meio de quem ouvia o comício (risos). Eu dizia: "Mas Artur, você está se arriscando aqui!”. Ele dizia: “É para ativar a luta de classes" (risos). Era um piadista. Flávio: Por isso, você fala que ocorre a transformação da classe em pobreza. Porque a esquerda, historicamente, o desafio dela sempre foi transformar pobreza em classe, e o que o governo Lula teria feito, e a Dilma continuado, e o Bolsa Família, mais especificamente, é transformar o que poderia ser uma voz dissonante de classe em pobreza.

Chico: É isso. O papel da esquerda ao longo da história foi esse. De São Francisco para São Marx. Os últimos doze anos é a regressão de São Marx para São Francisco, que é o santo que a minha mãe me deu o nome e é o grande santo da caridade cristã. Mas você olha para o panorama geral e só tem programa para os pobres. Numa velha piada, se um marciano caísse aqui: "Parece um país que só cuida dos pobres". A ironia da coisa é que só cuida dos pobres porque ele só produz pobres. Esse desenvolvimento capitalista que aí está e que vai seguir só produz pobres. Os pobres não são uma herança do passado, os pobres são a forma pela qual o capitalismo se desenvolve aqui. Então vai ter sempre pobre para atender. E os pobres vi- ram alvo de todas as políticas públicas.

Marcelo: Mas há mecanismo de ascensão, a famosa onda agora da chamada "classe C", que ganha 1500 reais por mês. Mas, pra quem não ganhava nada, ou ganhava 500, já é alguma coisa.

Chico: Mas você não acredita nisso, Marcelo?

Marcelo: Digamos que o próprio desenvolvimento do capitalismo gera uma diferenciação que não elimina a pobreza, mas talvez permita criar extratos sociais menos degradados, talvez igualmente ou mais explorados. Mas que permite às pessoas comprarem bens de consumo sem eliminar a pobreza. Flávio: A impressão que dá, e isso a gente pode ver no texto do Singer, é que ele analisa a classe, o setor mais baixo, que está ascendendo pelo consumo, mas tem também o setor de cima, que está subindo. Então, a questão que fica é: se quando acabar essa onda de crescimento, que pode durar muito, mas quando ela acabar, essa distância não vai ter diminuído. Então, acho que é por isso que o professor Chico está falando que a gente vai bater na parede da opressão de classe.

Marcelo: Sim, mas o que eu estou querendo dizer é que o desenvolvimento do capitalismo não leva, necessariamente, à pauperização. Ele leva à concentração de riqueza. Mandel já falava isso. Não é pela pauperização que se justifica a necessidade de uma transformação, mas é pela contradição entre os que têm mais e os que têm menos. É pela diferença de classe.

Chico: É, diferença de classe. Este país, como o Lula gosta de dizer, tem hoje o sétimo homem mais rico do mundo. Isso só ocorre quando você tem essa diferença. Isso não ocorre na França, na Itália, na Alemanha, na Inglaterra. Só ocorre neste caso. O homem mais rico do mundo é mexicano. Quem conhece o México sabe que aquilo é uma lástima. Ao norte da Cidade do México, existe a maior favela mundial. Não é comparável com as brasileiras. E tem o senhor Carlos Slim, que, ironicamente, tem o nome de magro (risos). Você não faz isso com redistribuição de renda. Isso só ocorre com altíssima concentração de renda. Você não encontra em nenhum outro país capitalista, salvo Bill Gates, alguém que se coloque nesse time dos mais 
ricos. Salvo Bill Gates, por causa do computador. Você não encontra um nome suíço, um nome alemão, um nome francês, um nome inglês. Encontra um brasileiro, o senhor Eike Batista, cujo pai foi ministro de Minas e Energias de Jango. E, no meu tempo, Celso Furtado dizia que ele era um homem de bem. O quê Elizeu Batista fez? Como ele foi presidente da Vale do Rio Doce durante quarenta anos, ele sabia de todas as reservas minerais do Brasil. Onde elas estavam e com quem estavam. Passou isso para o filho. Isso ocorre assim, não ocorre por distribuição de renda. Nem Marx explica. Só se explica, evidentemente, como uma formação de gangues, cuja riqueza se produz assaltando o Estado. Quer dizer, essa é uma das razões pelas quais eu não acredito no conto do André. Flávio: Na reunião do CENEDIC, o André Singer também fez uma relação entre essa sua mudança do final dos anos 1990 e uma aproximação com a perspectiva do Florestan Fernandes, da Revolução burguesa no Brasil, aquela aposta de que uma ruptura no capitalismo brasileiro tem que ser uma ruptura forte, violenta, ela não pode ser uma ruptura por reformas, ampliação de direitos. O que talvez o diferencie do próprio André: ele está fazendo essa aposta de que é possível você talvez chegar a mudanças por essa via. Você concorda com essa análise dele? Você está mais perto hoje daquele Florestan da Revolução burguesa no Brasil, que falava que não dava para fazer a luta por reformas, tinha que apostar numa ruptura violenta mesmo?

Chico: Eu vou responder de forma paradoxal. Eu estou mais próximo do Florestan, mas não acredito. Marcelo: Para haver ruptura, violenta ou não, tem de haver agentes querendo fazer a ruptura. O que o Chico está dizendo é que não tem agente, as pessoas estão sendo incorporadas à lógica do sistema. Enfim, é a hegemonia burguesa que está introjetada. Então, como ter ruptura ou reforma se as pessoas não querem fazer reforma nem ruptura?

Chico: As pessoas pensam, sonham e comem nos termos da hegemonia.

Flávio: O Florestan ainda tinha aquela ideia da hegemonia restrita da burguesia, que iria andar um pouco e iria sofrer uma ruptura. Não é hegemonia restrita que ele fala, mas é muito próximo. Aquela ideia de que a hegemonia da burguesia não é plena, e a ditadura era uma expressão de que ela precisava da força.

Chico: A ditadura era, mas hoje não.

Flávio: Hoje você acha que essa hegemonia é plena? Chico: É plena. Nós pensamos, comemos, sonhamos nos termos propostos pela hegemonia burguesa. Daí não sairmos para lugar nenhum. Isso não é eterno.

\section{Marcelo: Mas demora a mudar?}

Chico: Demora muito para mudar. Se, no Nordeste, as pessoas estão comendo. Esse é outro grave equívoco, e as ciências sociais são muito responsáveis por isso. Sempre se pensou que o Nordeste era um barril de pólvora, e não é. Tem conjunturas históricas em que ele se aproximou disso, mas depois passou. Se miséria fosse barril de pólvora, a Índia já teria explodido. Você tem um sistema de dominação, vou usar a palavra funcional, porque não encontro outra melhor, que, ao mesmo tempo em que as empregadas domésticas da minha mãe não votavam no usineiro, internamente elas nunca pediram carteira de trabalho. É uma forma de consenso. Aí eu não vou usar os velhos estigmas clássicos, de escravidão, eu não acredito mais nisso, eu estou noutra. A peculiaridade da dominação brasileira é o atraso como técnica de dominação. E não é a mesma coisa em todas as sociedades. Como é que os Estados Unidos controlam sua sociedade? Usando o individualismo como técnica de dominação. Você só terá êxito se for um indivíduo capaz e tal. No Brasil é diferente.

Marcelo: Mas isso não está mudando? No Brasil, você apontou um caminho parecido com o americano, mas degradado. Isso não envolve também uma mudança nesse sentido da valorização do individual, enfim, a ideia liberal clássica?

Chico: É. Só que a ideia liberal clássica, num país deste, não tem muito a oferecer. A ideia liberal clássica foi revolucionária no seu tempo, com uma dificuldade que nós, marxistas, temos que reconhecer. Revolucionária sim, foi revolucionária.

Marcelo: Hoje é muito difícil você encontrar, aqui 
em São Paulo, uma empregada que se submeta a trabalhar sem carteira assinada.

Chico: Não encontra. É uma diferença em relação a outras partes do Brasil notável. Você não encontra sequer empregada doméstica que queira prolongar sua jornada, dormir no trabalho. É uma mudança. Entre as minhas frágeis esperanças, eu espero que isso se espraie por todo Brasil, o que é difícil. Não precisa apelar para o Nordeste mais uma vez. Vai ao Rio de Janeiro para ver como muda, como é diferente. O estatuto do trabalho doméstico no Rio até antecipou muita coisa que já ocorre em São Paulo, mas parou. Tudo isso são movimentos moleculares que o próprio desenvolvimento do capitalismo faz. Isso não é grande reforma. Então, vai ocorrendo porque, se nós não estamos muito enganados, e se Marx ainda tem algum valor, o que o capitalismo compra é o tempo de trabalho, e o outro lado também sabe medir esse tempo de trabalho. Quando os dois comprimirem, isso a gente melhora. A questão é essa. Não vejam como pessimismo larvar, mas a corrida mundial é muito acelerada. Cada novo desenvolvimento obriga você, a gente sabe há tempos, a tornar obsoleta a parte do que estava atrás e tentar adaptar-se e até inventar o que está pela frente. Isso faz com que o caminho tradicional que a classe operária percorreu não possa ser percorrido. E aí, me aproximando e me distanciando de Florestan, eu não acredito que vai haver nenhuma ruptura violenta. Porque é um conformismo morno, uma coisa difícil de definir. Sem apelar para moralismo udenista, fica difícil de ver o que é isso. É claro que muito disso é sua própria interpretação e seus próprios desejos de que fosse diferente. Mas é assim que você vê o mundo. Quando eu entrei no Partido Socialista eu pensei que ia ser fácil (risos).

Flávio: Acho que é isso, foi uma boa entrevista.

Marcelo: Para finalizar, pode citar autores que tiveram alguma influência maior sobre você?

Chico: Eu estou muito desatualizado, não leio mais teoria. Só leio romance. No passado, eu gostava muito da teoria da regulação. O Robert Boye e o Michel Aglietta eram meus autores preferidos. Exatamente porque eles vêm de uma tradição gramsciniana, e essa tradição nos levou a valorizar o institucional. Ao contrário dos marxistas ortodoxos, para quem o institucional é balela burguesa, eles valorizavam muito o institucional e é a partir daí que a teoria da regulação decola. Mas isso é da época em que eu sonhava, na época da teoria do antivalor.

Recebido para publicação em 29 de outubro de 2012 Aceito em 21 de dezembro de 2012

\section{REFERÊNCIAS}

CARDOSO, Fernando Henrique. Autoritarismo e democratização. Rio de Janeiro: Paz e Terra, 1975.

; FALETTO, Enzo. Dependência e desenvolvimento na América Latina: ensaio de interpretação sociológica. Rio de Janeiro: Zahar, 1975.

FERNANDES, Florestan. A revolução burguesa no Brasil: ensaio de interpretação sociológica. São Paulo: Globo, 2006 .

JINKINGS, Ivana; RIDENTI, Marcelo; MAAR, Wolfgang Leo. Entrevista: Francisco de Oliveira. Revista Margem Esquerda, São Paulo, n. 10, novembro de 2007.

KIERNAN, V. G. Estados Unidos: o novo imperialismo. Rio de Janeiro: Record, 2009.

NAVES, Rodrigo. Entre mortos e feridos: Novos Estudos e CEBRAP de 1987 a 1995. Novos estud. - CEBRAP, São Paulo, n. 75, p. 15-21. jul., 2006. Disponível em: www.scielo.br/ pdf/nec/n75/a02n75.pdf. Acesso em: 26 jan. 2013.

OLIVEIRA, Francisco de. A economia da dependência imperfeita. Rio de Janeiro: Graal, 1980.

Além da transição, aquém da imaginação. Novos estud. - CEBRAP, São Paulo, n. 12, jul., 1985.

Apocalipse Now: o 'Coração das Trevas' do Neoliberalismo In: OLIVEIRA, Francisco de; COMIN, Alvaro (Org.). Os cavaleiros do antiapocalipse. São Paulo: Entrelinhas, 1999.

Aves de arribação: a migração dos intelectuais. Lua Nova, São Paulo, v. 2, n. 3, p. 20-6, out./dez, 1985.

Condições institucionais do planejamento. Revista Civilização Brasileira, Rio de Janeiro, v. 5-6, p. 3947, 1966.

. Crítica à razão dualista. São Paulo: Vozes, 1981.

E agora PT? Novos estud. - CEBRAP, São Paulo, n. 15, jul., 1986.

Elegia para uma re(li)gião: Sudene, Nordeste planejamento e conflito de classes. Rio de Janeiro: Paz e Terra, 1977.

Medusa ou as classes médias e a consolidação democrática. In: O’DONNEL, G.; REIS, F. W. (Org.). Dilemas e perspectivas da democracia no Brasil. São Paulo: Vértice, 1988. p. 282-295.

. et al. Quanto melhor, melhor: O Acordo das Montadoras. Novos estud. - CEBRAP, São Paulo, n. 36, julho 1993. 
O elo perdido: classe e identidade de classe. São Paulo: Brasiliense, 1987

O Plano de ação econômica do governo Castello Branco: por que não terá êxito. Revista Civilização Brasileira, Rio de Janeiro, v. 1, p. 114-128, 1965.

(Org.). Os direitos do antivalor: a economia polí tica da hegemonia imperfeita. São Paulo: Vozes, 1998.

; PAOLI, Maria C. (Org.). Os sentidos da democracia. Petrópolis: Vozes, 2000.

Privatização do público, destituição da fala e anuacão da política: o totalitarismo neoliberal In: OLIVEIRA Francisco de; PAOLI, Maria C. (Org.). Os sentidos da democracia. Petrópolis: Vozes, 2000.
RANCIÈRE, Jacques. O desentendimento. São Paulo: Editora $34,1996$.

SINGER, André. Raízes sociais e ideológicas do lulismo. Novos estud. - CEBRAP, São Paulo, n. 85, p. 83-102, nov., 2009. Disponível em: http://novosestudos.uol.com.br/ acervo/acervo_artigo.asp?idMateria=1356. Acesso em: 28 jan. 2013

SINGER, Paul. Crítica e rememoracão. In: RIZEK, Cibele S.; ROMÃO, Wagner M. Francisco de Oliveira: a tarefa da crítica. Belo Horizonte: Ed. da UFMG, 2006. p. 16.

Marcelo Siqueira Ridenti - Doutor em Sociologia. Professor Titular de Sociologia na Universidade Estadual de Campinas. Tem experiência na área de Sociologia, atuando principalmente nos seguintes temas: cultura, arte e política, esquerda brasileira, intelectualidade brasileira, pensamento marxista, ditadura militar brasileira, anos 1960. Publicações recentes: Brasilidade revolucionária - um século de cultura e política (Ed. Unesp, 2010); Em busca do povo brasileiro: artistas da revolução, do CPC à era da tv (Record, 2000); $O$ fantasma da revolução brasileira (Ed. UNESP, 2a. ed. revista e ampliada, 2010).

Flávio da Silva Mendes - Doutorando em Sociologia. Mestre em sociologia pela UNICAMP. Desenvolve pesquisas sobre a política na América Latina e a trajetória de intelectuais no Brasil. Publicou o livro: Hugo Chávez em seu labirinto: o Movimento Bolivariano e a Política na Venezuela, em co-edição entre Alameda e FAPESP (São Paulo/SP), em 2012. 